\title{
KREPŠININKŲ (JAUNUČIŲ) VALIOS SAVYBĖS
}

\author{
Romualdas Malinauskas, Almantas Dumbliauskas
}

Lietuvos kūno kultūros akademija, Kaunas, Lietuva

\begin{abstract}
Romualdas Malinauskas. Profesorius socialinių mokslų daktaras. Lietuvos kūno kultūros akademijos Sporto pedagogikos ir psichologijos
\end{abstract} katedros vedejjas. Mokslinių tyrimų kryptis - sporto pedagogų ir sportininkų socialinio psichologinio rengimo ypatumai.

\section{SANTRAUKA}

Norint pasiekti didžiausiu laimèjimu sporte, bütina labai stipri valia. Sportininko valia ugdoma fizinio, techninio, taktinio ir psichologinio rengimo metu. Jaunučiu amžius ypač tinkamas krepšinǐ žaidžiančiu berniuku ir mergaičiu valios savybèms ugdyti. Parinkdamas sportininkui fizini pratima ir ji dozuodamas, treneris privalo atsižvelgti ir $\dot{z}$ to pratimo bei jo dozés poveiki valiai: sudaromi sunkumai turi didèti pamažu, reikalauti iš sportininko valios pastangu, kartu büti jam ìveikiami.

Straipsnyje analizuojama, kokios valios savybès yra būdingiausios krepšininkams (jaunučiams), kaip skiriasi krepšinǐ žaidžiančiu berniuku ir mergaičiu valios savybiu raiškos lygis. Siekiant užsibrěžto tikslo buvo sprendžiami tokie uždaviniai: atskleisti krepšininku (berniuku ir mergaičiu) valios savybes, taikant tiriamuju savęs vertinimo metodika, ištirti krepšininku (berniuku ir mergaičiu) valios savybes, taikant ekspertu vertinimo metodika. Keliama prielaida, kad krepšin̨ žaidžiančiu berniuku (jaunučiu) valios savybiu raiškos lygis yra aukštesnis nei mergaičiu (jaunučiu).

Taikyti šie tyrimo metodai: anketinès apklausos (modifikuota T. Dembo-S. Rubinštein metodika valios savybiu raiškos lygiui nustatyti (cituojama iš Елисеeв, 1994)), ekspertu vertinimo metodika ryžtingumui ir iniciatyvumui tirti (Palaima, 1984), matematinè statistika ( $\chi^{2}$ kriterijus).

Taikant atsitiktinès atrankos procedūra Kauno apskrities krepšinǐžaidžiančiu jaunučiu sporto klubuose, 1116 tiriamuju imti pateko Kauno krepšinio klubo „Žvaigždžiu tornadas “ berniuku komandos, Alytaus sporto mokyklos ,,Jotvingiu“” ir , Vidzgirio “ mergaičiu komandos. Ištirti 58 (15-16 m.) jaunieji krepšininkai ir 58 (15-16 m.) krepšininkès.

Taikant anketinès apklausos metoda buvo nustatyta, kad krepšininku berniuku ir mergaičiu pasiskirstymas pagal ryžtinguma ir drqsumq statistiškai patikimai skiriasi: berniukai ryžtingesni $(p<0,01)$ ir drasesni $(p<0,05)$ už mergaites. Be to, berniukai yra ir tikslingesni $(p<0,05)$. Ištyrus krepšininku (berniuku ir mergaičiu) valios savybes, taikant ekspertu vertinimo metodika, paaiškejjo, kad krepšininkai (berniukai) ryžtingesni ( $<<0,01)$ nei krepšininkès mergaitès, tačiau taikant $\chi^{2}$ kriteriju nustatyta, kad 15-16 metu jaunieji krepšininkai ir krepšininkès statistiškai patikimai nesiskiria pagal iniciatyvuma $(p>0,05)$.

Raktažodžiai: valia, valios savybès, krepšinis.

\section{IVADAS}

$\mathrm{N}$ orint pasiekti didžiausių laimèjimų sporte, būtina labai stipri valia. Sportininko valia ugdoma fizinio, techninio, taktinio ir psichologinio rengimo metu. Jaunučių amžius ypač tinkamas krepšini žaidžiančių berniukų ir mergaičiu valios savybėms ugdyti. Parinkdamas sportininkui fizini pratimą ir ji dozuodamas, treneris privalo atsižvelgti ir $\mathfrak{i}$ to pratimo bei jo dozès poveiki valiai: sudaromi sunkumai turi didèti pamažu, reikalauti iš sportininko valios pastangu, kartu būti jam ịveikiami. Atlikdamas fizinius prati- mus ir sportinius veiksmus, sportininkas susiduria su įvairiomis kliūtimis ir sunkumais, kuriems iveikti reikia valios pastangų. Valios pastanga vadiname žmogaus išgyvenamą savitą psichinę itampac, susijusią su valios motyvu igyvendinimu veikloje bei dèmesio reguliavimu (jo nukreipimu ir išlaikymu ties kuriuo nors vidinès ar išorinès aplinkos objektu). Sunkumai sudaro pačios sporto šakos esmę: ugdant sportininko valią, tereikia i juos atsižvelgti (Malinauskas, 2003). Krepšinis, kaip ir daugelis kitų sporto šakų, reikalauja iš 
sportininko aktyvios judejjimo veiklos, komandiniai žaidèjų veiksmai turi būti gerai organizuoti. Tyrimai rodo, kad svarbu vaidmeni reguliuojant bendravimą žaidimo metu atlieka valios savybès (Meidus, 1999; 2005 a, b). Valios savybès labai pasireiškia žaidimo veiksmuose (Meidus, 1999). Dažniausiai tiriant analizuojamos svarbiausios rankininkių valios savybės ir šiu savybių raiškos kaita (Meidus, $2005 \mathrm{a}, \mathrm{b}$ ). Analizuojant rankininkių emocines valios savybes buvo nurodyta, kad rankiniui būdingiausios yra šios: tikslo siekimas, pasitikejimas, atkaklumas, drausmè (Meidus, 1999). Manome, kad atsižvelgiant i kitų autorių ankstesnius mokslo darbus (Palaima, 1976; Kasiulis, Čižauskas, 1997) būtina atkreipti dèmesị ir i sportininkų valios savybių - drąsumo, ryžtingumo, iniciatyvumo - raišką.

Pastaruoju metu galbūt šiek tiek daugiau dèmesio mokslo darbuose skiriama ne tiek sportininkų valios savybių tyrimo problemoms, kiek sportininkų savireguliacijos, savikontrolès ypatumams (Соколова, 1994; Muraven, Dianne, 1998; Malinauskas, Malinauskienė, 2004; Williams et al., 2000). Pabrèžiama, kad asmenybės gebejjimas nuolat save kontroliuoti yra vienas iš jos valios brandumo rodiklių, o savireguliacija, kaip tikslingas savo paties aktyvumo reguliavimas, apima valingo aktyvumo tikslo iškèlimą, reikšmingu veiklos sąlygu modelio, veiksmu programos sukūrimą, valingą veiklos koregavimą. Nurodoma, kad savireguliacijos ir savikontrolès svarba yra neabejotina (Легостаев, 1995; Волков, 1999; Смоленцева, 2001). Teigiama, kad sportininku savireguliacijos ir savikontrolès stiprinimas yra pripažinta nūdienos sporto psichologijos tyrimų kryptis (Смоленцева, 2001), tačiau tuomet sportininko valios ugdymo problematika tarsi lieka šešèlyje (Смирнов, 1999). Manome, kad sportininku valios savybiu tyrimas nepraranda savo aktualumo, nes stipri sportininku valia laiduoja sportinès veiklos sèkmę (Горбунов, 1992, 2001).

Literatūros šaltinių (Горбунов, 1992, 2001, 2002) analizė leidžia teigti, kad krepšininku, ypač jaunučių, valios savybių raiškos problema ištirta nepakankamai. Svarbu išsiaiškinti, kokia krepšininkų valios savybių (tikslingumo, iniciatyvumo, ryžtingumo, drąsumo) raiška. Probleminis klausimas yra toks: kurios valios ypatybès būdingiausios krepšininkams berniukams ir kurios mergaitėms. Temos naujumas yra tas, kad būtent krepšininkų valios savybės yra nepakankamai tyrinètos.
Tyrimo tikslas - išanalizuoti krepšininkų (jaunučiu) valios savybes.

\section{Uždaviniai:}

1. Ištirti krepšininkų (berniukų ir mergaičių) valios savybes, taikant tiriamujų savęs vertinimo metodika.

2. Atskleisti krepšininkų (berniukų ir mergaičių) valios savybes, taikant ekspertų vertinimo metodiką.

Hipotezè. Tikètina, kad krepšinị žaidžiančių berniukų (jaunučių) valios savybių raiškos lygis yra aukštesnis nei mergaičiu (jaunučiu).

\section{TYRIMO METODAI IR ORGANIZAVIMAS}

Buvo taikomi šie metodai:

1. Literatūros šaltinių analizè.

2. Anketinè apklausa:

- modifikuota T. Dembo-S. Rubinštein metodika valios savybiu raiškos lygiui nustatyti (Елисеев, 1994);

- ekspertu vertinimo metodika ryžtingumui ir iniciatyvumui tirti (Palaima, 1984).

3. Matematinè statistika ( $\chi^{2}$ kriterijus).

Modifikuota T. Dembo-S. Rubinštein metodika buvo taikoma jaunujų krepšininkų tikslingumui, iniciatyvumui, ryžtingumui, drąsumui nustatyti. Šios metodikos panaudojimo galimybès labai plačios: ja galima tirti tiek ikimokyklinio, tiek paauglių, tiek suaugusiujų valios savybes. Atkarpose su penkiomis padalomis tiriamasis turejo pieštuku pažymèti tą vietą, kurią jis užima pagal tikslingumą, iniciatyvumą, ryžtingumą, drąsumą. Jei rodiklio reikšmė yra didesnè arba lygi 4 balams, tai komponento lygis yra aukštas, jei reikšmè $2-3$ balai - vidutinis, o reikšmè nuo 0 iki 1 balo reiškia žemą lygi.

Buvo svarbu išsiaiškinti, kaip tiriamasis supranta, kas yra tikslingumas, iniciatyvumas, ryžtingumas, drąsumas. Juk kiekvienas žmogus šias sąvokas supranta savaip, suteikia joms ypatingą prasmę. Todèl tiriamiesiems visuomet buvo aiškinama šiu sąvoku prasmé, kad jie vienodai suvoktų valios savybes. Metodikos paprastumas ir nesudètinga tyrimo procedūra ịrodo jos neginčijamus privalumus taikant tyrimams, tačiau, kita vertus, ją ne visada galima panaudoti kaip individualią diagnostinę priemonę. Metodika aprobuota atliekant autoriaus monografini tyrimą (Malinauskas, 2006).

Ryžtingumui ir iniciatyvumui vertinti buvo taikoma klasikinè ekspertų vertinimo metodika 
(Palaima, 1984). Ekspertai tiriamujų valios savybes vertino penkių balų sistema. Jei rodiklio reikšmė yra didesnè arba lygi 4 balams, tai komponento lygis vertinamas kaip aukštas, jei reikšmè 2-3 balai - vidutinis, o reikšmė nuo 0 iki 1 balo reiške žemą lygi. Apie ryžtingumą buvo sprendžiama iš to, kaip jaunieji krepšininkai prisitaikė žaisti trijulių krepšini $(3 \times 3)$, pasikeitus gynejjams. Žaidimo metu buvo vykdomos dvi atakos. Po teisejjo švilpuko keičiami gynèjai. Jei žaidejją persekiojo aukštesnis gynèjas, o žaidejjo rezultatyvumas nesusilpnèjo, tai reišké žaidejo ryžtingumą. Apie žaidejo iniciatyvumą buvo sprendžiama iš baudu metimo taiklumo prieš fizini krūvị ir po jo. Buvo metama po penkis baudos metimus i krepši prieš fizini krūvi ir penki po jo. Fizinis krūvis buvo toks: jaunučiams reikejo bègti per visą sporto salę, paliesti liniją priešingoje salès pusejje, o grižus mesti ị krepši nuo baudos linijos.

Tyrimo organizavimas. Tiriamieji atsitiktine tvarka (pagal atsitiktiniu skaičiu lenteles) atrinkti iš Kauno ir Alytaus apskričių krepšinio klubu sąrašo. Taikyta dvipakope atranka: iš pradžiu atrinkti klubai, paskui ištirti visi juose sportuojantys jaunučiai (krepšini žaidžiantys moksleiviai ir moksleivess). I tiriamają imti pateko Kauno krepšinio klubo „Žvaigždžių tornadas“ berniuku komandos ir Alytaus sporto mokyklos „Jotvingių“ bei „Vidzgirio“ mergaičių komandos. Šiose komandose sportuoja vidutinio meistriškumo jaunučiai (15-16 m. krepšininkai ir krepšininkès). Tyrimas vyko prieš pratybas, stebint krepšinio treneriams. Buvo planuojama ištirti 120 sportininku. Kadangi dèl ligos keturi sportininkai nedalyvavo, tirta $116-58$ berniukai ir 58 mergaitès.

\section{REZULTATAI}

Pasitelkus modifikuotą T. Dembo-S. Rubinštein metodiką atskleista, kad ryžtingesni yra berniukai $\left(\chi^{2}(2)=9,36\right.$; p $\left.<0,01\right)$. Ryžtingumas — tai valios savybè, pasireiškianti gebejjimu laiku priimti sprendimą atsakingomis situacijomis. $62 \%$ berniukų nurode, kad jie yra labai ryžtingi (1 pav.). Didelis ryžtingumas būdingas 34\% mergaičių. Tai rodo, kad ryžtas siekti užsibrèžto tikslo, nugalèti varžovą yra būdingesnis jauniesiems krepšininkams, o mergaitėms užsibrèžto tikslo siekti yra sunkiau. Rezultatai rodo, kad $41 \%$ mergaičių ir $33 \%$ berniuku apibūdino save kaip vidutiškai ryžtingus. Keletas mergaičiu ir berniukų nurodè, kad jų ryžtingumas yra mažas.

Tyrème ir kitą jaunujų krepšininkų valios savybę - drąsumą. Drąsumas - tai valios savybè, kuri padeda įveikti baimę pavojingomis situacijomis. Nepagrịsta drąsa, beprasmiška rizika pavojaus akivaizdoje nėra tikros drąsos požymis. Ištyrus jaunučių drąsumą nustatyta, kad 65\% krepšininkų berniuku ir 57\% krepšininkių mergaičių yra labai drąsūs (2 pav.). Vis dèlto $24 \%$ mergaičiuc ir 7\% berniukų labai nedrąsūs. Galima teigti, kad šiems jaunučiams sunku įveikti baimę itemptu rungtynių metu. Taikant $\chi^{2}$ kriterijų nustatyta, kad krepšininkų berniukų ir mergaičių pasiskirstymas pagal drąsumą statistiškai patikimai skiriasi: berniukai yra drąsesni $\left(\chi^{2}(2)=6,83 ; p<0,05\right)$.

Tyrimo rezultatai rodo, kad tikslingumą (tikslingumas - tai tokia valios savybè, kai gebama kelti tikslus ir jų siekti) ivvertino kaip dideli 43\% berniukų ir 28\% mergaičių ( 3 pav.). Mažas tikslingumas nustatytas tik vienam berniukui ir septynioms mergaitėms. Tikslingumas krepšininkams

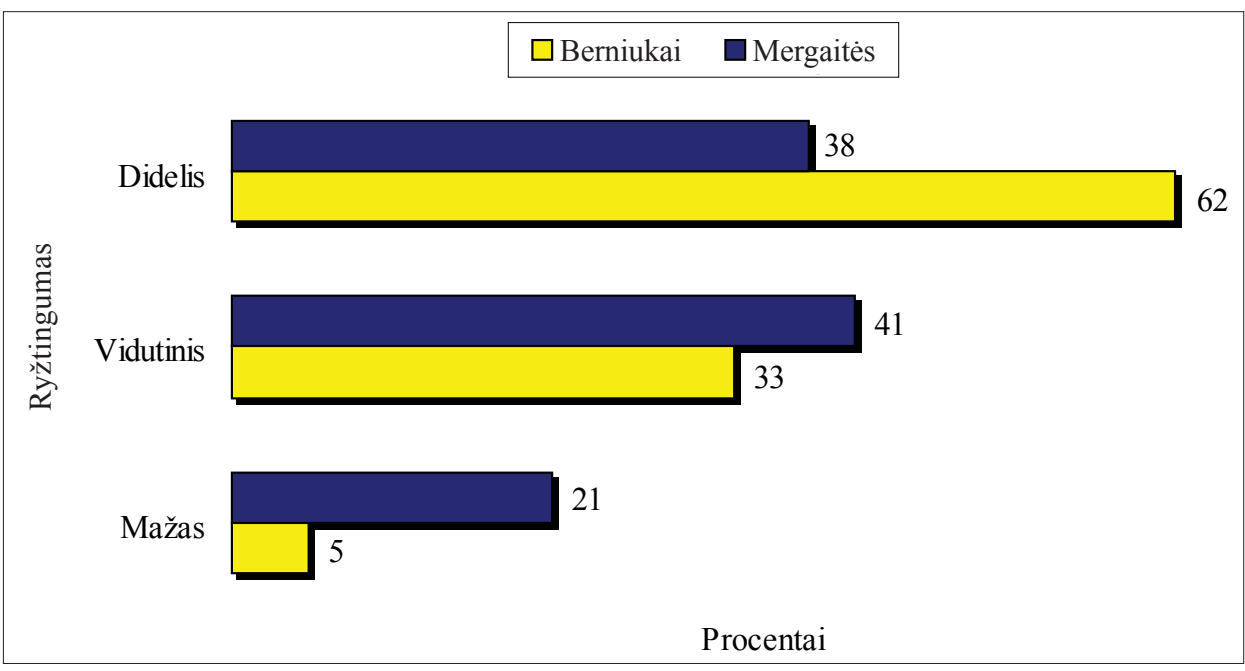

1 pav. Tiriamųjų pasiskirstymas pagal ryžtingumą 
2 pav. Tiriamųjų pasiskirstymas pagal drąsumą

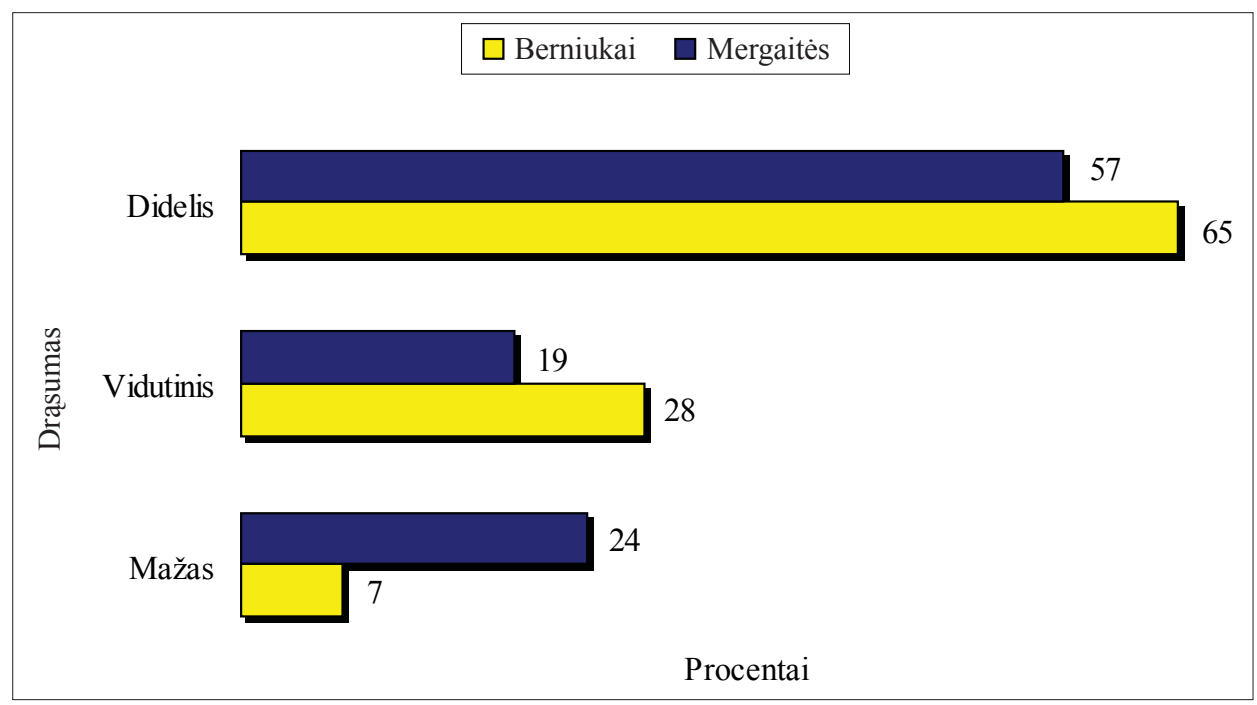

3 pav. Tiriamųjų pasiskirstymas pagal tikslingumą

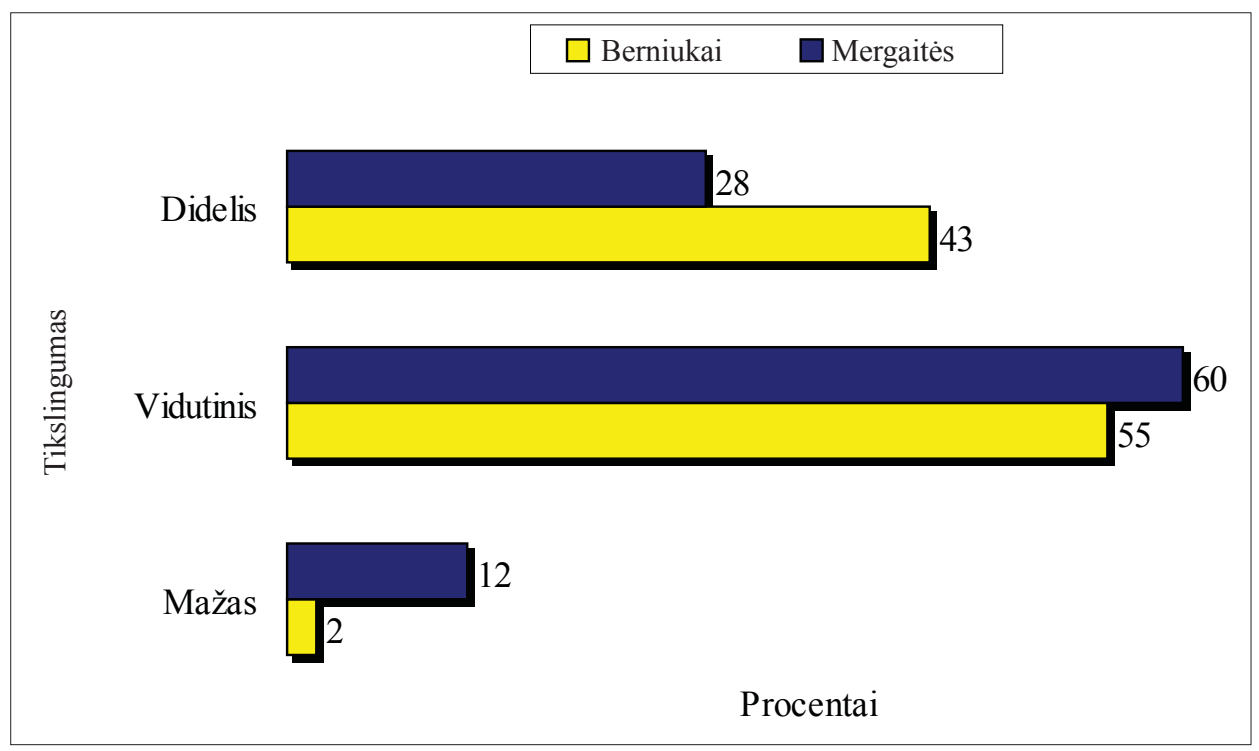

4 pav. Tiriamųjų pasiskirstymas pagal ryžtingumą, taikant ekspertų vertinimo metodiką

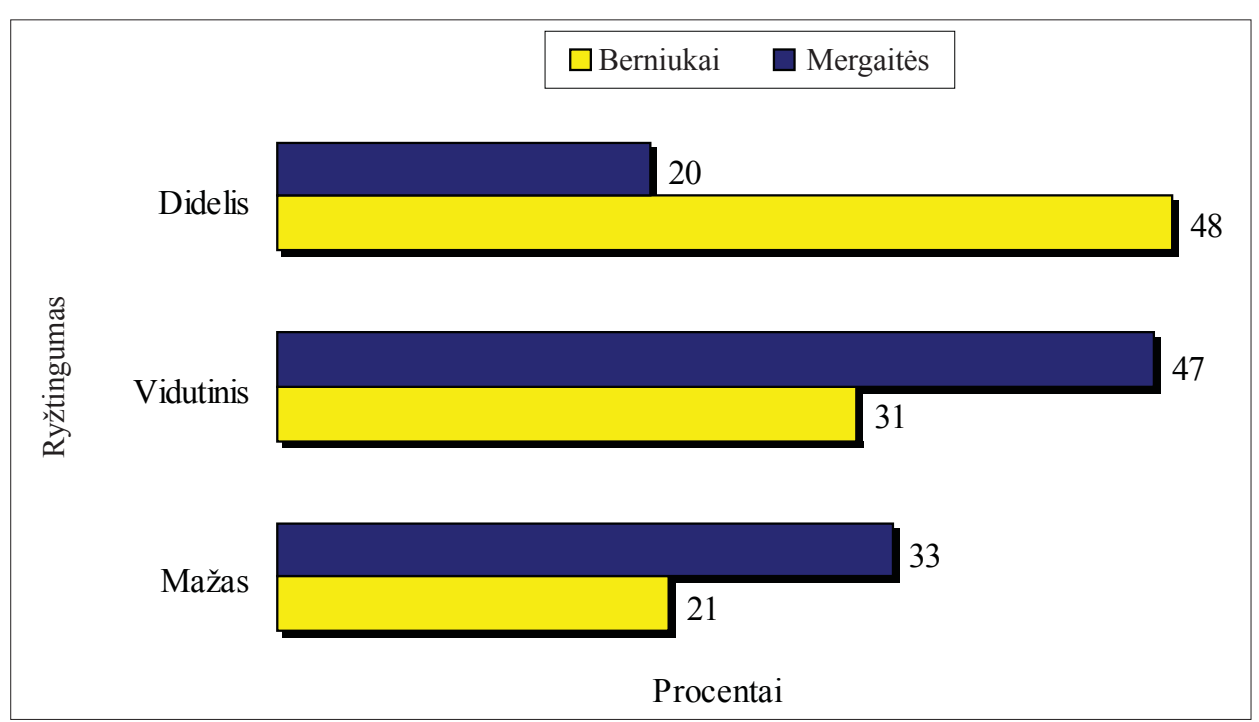

yra labai svarbus, kadangi kuo aiškiau jaunieji krepšininkai suvokia savo tikslus, tuo atkakliau jų siekia. Pasitelkus $\chi^{2}$ kriterijų nustatyta, kad krepšininkų berniukų ir mergaičiu pasiskirstymas pagal tikslingumą statistiškai patikimai skiriasi: berniukai tikslingesni $\left(\chi^{2}(2)=6,61 ; p<0,05\right)$.

Ištyrus jaunuosius krepšininkus paaiškejjo, $\operatorname{kad} 60 \%$ berniukų ir 59\% mergaičiu yra labai 
iniciatyvūs. Iniciatyvumas - tai valios savybè, kai žmogus ne tik pats veikia kitu neskatinamas, bet ir kitus skatina. Iniciatyvumo trūkumas padaro sportininko veiklą priklausomą nuo trenerio stimuliavimo. Iniciatyvūs sportininkai tikslo siekia nepaisydami laikinų nesèkmių arba sunkumų. Tyrimo rezultatai parode, kad berniukai ir mergaitès nesiskyrè pagal iniciatyvumą $\left(\chi^{2}(2)=0,90\right.$; $\mathrm{p}>0,05)$.

Norint patikrinti, ar ekspertu vertinimai nesiskiria nuo pačių tiriamuju savo valios savybių vertinimo, jaunučių ryžtingumas ir iniciatyvumas buvo tiriamas pasitelkus ekspertų vertinimo metodiką.

Taikant ekspertų vertinimo metodiką atskleista, kad $48 \%$ berniukų ir $20 \%$ mergaičių būdingas didelis ryžtingumas. Trečdalis berniukų ir pusè tirtų mergaičiu yra vidutinio ryžtingumo. Pasitelkus $\chi^{2}$ kriterijų nustatyta, kad krepšininkų berniukų ir mergaičiu pasiskirstymas pagal ryžtingumą statistiškai patikimai skiriasi: berniukai yra ryžtingesni $\left(\chi^{2}(2)=9,78 ; p<0,01\right)$.

Taikant ekspertų vertinimo metodiką atskleista, kad puse tirtu berniuku ir mergaičių labai iniciatyvūs, o trečdalis - vidutiniškai iniciatyvūs. Tyrimo rezultatai taikant ekspertų vertinimo metodiką parode, kad berniukai ir mergaitès nesiskyrè pagal iniciatyvumą $\left(\chi^{2}(2)=0,34\right.$; $\mathrm{p}>0,05)$.

\section{REZULTATŲ APTARIMAS}

Hipotezė, kad krepšini žaidžiančių berniukų (jaunučių) valios savybių raiškos lygis yra aukštesnis nei mergaičiu (jaunučių), pasitvirtino. Rezultatai parodè, kad ekspertų vertinimai nesiskyrè nuo pačių tiriamujų savo valios savybių vertinimo. Paaiškejjo, kad berniukai yra ryžtingesni, drąsesni, tikslingesni. Nors mes netyreme krepšininkų (jaunučių) valios savybių sąsajų su sportinès veiklos rezultatais, visgi manome, kad galima pritarti mokslo darbu (Meidus, 1999, 2005 a; Williams et al., 2000) išvadoms, kuriose akcentuojama, kad pergalę pasiekia tos komandos, kurių žaidejai rodo didesnes valios pastangas, tiksliai diferencijuodami ir suvokdami kiekvienu atsakingu veiklos momentu iškeltus uždavinius. Pavyzdžiui, irodyta, kad valios savybių trūkumas gali smarkiai pabloginti rankininkių komandos žaidimo efektyvumą (Meidus, 1999). Manome, kad atsakymas i klausimą, kaip valios savybių trūkumas galètu lemti krepšinio komandos žaidimo efektyvumą, galètu būti formuluojamas tik atlikus tolimesnius tyrimus.

Mokslo darbuose (Горбунов, 2001, 2002) atskleista, kad ilgujų ir trumpujų nuotolių bėgikų valios savybiu raiška skiriasi, tačiau tuo atveju buvo tiriami jaunuoliai (17-24 m.) lengvaatlečiai. Publikacijų, kuriose būtų analizuojamos jaunučių valios savybès, mums nepavyko aptikti.

Daugiausia publikacijose (Meidus, 1999, 2005 a) analizuojamos rankininkių valios savybès. Tyrimai rodo, kad rankininkių valios savybès yra tiesiogiai susijusios su fiziniu ir techniniu ju parengtumu (Meidus, 1999, 2005 a). Atskleista, kad didesnio meistriškumo rankininkių valios savybiu raiškos lygis buvo statistiškai patikimai aukštesnis. Kadangi mes tyrème tik krepšininkų (jaunučiu) valios savybes, tai galètume kelti prielaidą, kad galbūt didelio meistriškumo krepšininkų valios savybių raiškos lygis būtų aukštesnis.

Galime pritarti L. Meidui (2005 c), kad sportininko valios savybėms ugdyti nèra specialiu pratybų ar specialių fizinių pratimų, bet ir per pratybas, ir namie sportininkas gali veikti bei stebeti save iš šalies. Tai labai geras valios savybiu ugdymo būdas, padedantis mokytis issisąmoninti savo emocijas ir elgesi, tapti kantresniems (Malinauskas, 2003).

Naujausi tyrimai (Ryska, 2004) parodè, kad patiriamas malonumas sportinès veiklos metu priklauso nuo fizinių pratimų intensyvumo, pratybų trukmès ir dažnio. Pavyzdžiui, sportininkų valiai ugdyti labiausiai tinka šios pratybos: krepšinio, aerobikos, jojimo, plaukimo (Ryska, 2004). Be to, ugdant sportininko valią, reikia atsižvelgti i jo asmenybès (temperamento, charakterio) savybes ir dozuoti fizinį bei psichini krūvi - didinti ji labai nuosekliai ir pamažu (Malinauskas, 2003). Pavyzdžiui, drąsumą, iniciatyvumą, ryžtingumą (jo komponentą - greitą sprendimo priemimą) lengviau gali išsiugdyti choleriško temperamento sportininkas negu flegmatikas. Ne mažiau svarbią valios savybę savitvardą ir kitą ryžtingumo komponentą - apgalvoto sprendimo prièmimą, taip pat atkaklumą lengviau išsiugdyti flegmatiško temperamento žmogui. Melancholiškam sportininkui reikia daug trenerio demesio, takto ir globos, dozuojant fizini ir psichini krūvị, o ir sunkumus reikia didinti pamažu (Malinauskas, 2003).

Apibendrindami mūsų ir kitų autorių tyrimų rezultatus galime teigti, kad sportininkų valios savybių vertinimas ir ugdymas - svarbus kiekvieno 
trenerio uždavinys, kryptingai sprendžiamas pratybų ir rungtynių metu.

Manome, kad papildomai reikètu ištirti didelio meistriškumo krepšininkų valios savybių ypatumus, nes negalima apsiriboti tik jaunučiu tyrimo duomenimis.

\section{IŠVADOS}

1. Taikant tiriamujų apklausos (savęs vertinimo) metodiką buvo nustatyta, kad 15-16 metų krepšininkai berniukai yra ryžtingesni $(p<0,01)$ ir drąsesni $(p<0,05)$ už to paties amžiaus mergaites. Be to, jaunieji krepšininkai berniukai yra ir tikslingesni $(p<0,05)$ nei krepšininkès mergaitès.

2. Ištyrus $15-16$ metų krepšininkų (berniukų ir mergaičių) valios savybes, taikant ekspertu vertinimo metodika, pasitvirtino prognozé, kad krepšininkai berniukai ryžtingesni $(p<0,01)$ nei krepšininkès mergaitès.

\section{LITERATŪRA}

Kasiulis, J., Čižauskas, A. (1997). Bendrasis psichologinis krepšininku rengimas. Kaunas: LKKI.

Malinauskas, R., Malinauskienè, V. (2004). Psichologinio rengimo programos poveikis didelio meistriškumo stalo tenisininku savireguliacijai ir savikontrolei. Sporto mokslas, 2 (36), 53-57.

Malinauskas, R. (2006). Sporto pedagogu ir sportininku socialinio psichologinio rengimo ypatumai: monografija. Vilnius: LSIC.

Malinauskas, R. (2003). Sporto psichologijos pagrindai: studiju knyga. Kaunas: LKKA.

Meidus, L. (1999). Rankininkų emocinių valios savybių pasireiškimas ir jų formavimas. Sporto mokslas, 3, $33-36$.

Meidus, L. (2005 a). Rankininkiu squeikos psichologija: monografija. Vilnius: VPU.

Meidus, L. (2005 b). Sportininkių (rankininkių) valios ugdymo galimybès. Acta paedagogica Vilnensia, 15, $156-164$

Meidus, L. (2005 c). Sporto psichologija. Vilnius: VPU. Muraven, M., Dianne, T. (1998). Self-control as limited resource: Regulatory depletion patterns. Journal of Personality and Social Psychology, 74 (3), 774-789.

Palaima, J. (1984). Bendrosios ir sporto psichologijos praktikos darbai. Kaunas: LKKI.

Palaima, J. (1976). Sportininko valios ugdymas. Kaunas: LKKI.

Ryska, T. A. (2004). Enjoyment of evaluative physical activity among young participants: The role of self-handicapping and intrinsic motivation. Child Study Journal, 33 (4), 213-234.

Williams, K. J., Donovan, J. J., Dodge, T. L. (2000). Selfregulation of performance: Goal establishment and goal revision processes in athletes. Human Performance, 13 (2), 159-180.

Волков, И. П. (1999). Медитация как метод спортивной психологий. Теория и практика физической культуры, $10,34-36$.
Горбунов, Ю. Я. (1992). Индивидуальный стиль волевой активности и его формирование у старших школьников: автореф. канд. дис. Пермь: ПГУ.

Горбунов, Ю.Я. (2002). Исследование волевой активности в структуре индивидуальности спортсмена. Теория и практика физической культуры, 7, 37-38.

Горбунов, Ю. Я. (2001). Сравнительная характеристика проявления волевой активности в различных видах лёгкой атлетики. Теория и практика физической культурь 3, 33-35.

Елисеев, О. П. (1994). Конструктивная типология и психодиагностика личности. Псков: Областной институт.

Легостаев, Т. Н. (1995). Результаты применения аутогенной тренировки в учебном процессе со студентами. Теория и практика физической культуры, $4,16-18$.

Смирнов, Н. Б. (1999). Психологические механизмы эмоционально-волевой саморегуляции в спорте. Теория и практика физической культуры, 12, 28-33.

Смоленцева, В. Н. (2001). Психорегуляция в спорте. Теория и практика физической культуры, 5, 19-22.

Соколова, Л. А. (1994). Изучение индивидуально-типологических особеностей саморегулирования и успешности спортивной деятелности. Теория и практика физической културы, 2, 39-42. 


\title{
WILL TRAITS OF BASKETBALL PLAYERS CADETS
}

\author{
Romualdas Malinauskas, Almantas Dumbliauskas \\ Lithuanian Academy of Physical Education, Kaunas, Lithuania
}

\begin{abstract}
In order to reach the highest achievements in sport, strong will is a must. The will of athlete is cultivated during physical, technical, tactical and psychological training (Горбунов, 2001). Cadet age is suitable in particular to develop volitional features in boys and girls that play basketball. When choosing a physical exercise and its dosage for an athlete, a trainer needs to take into consideration the impact of that exercise and its dose on the athlete's will: assigned loads have to be increased gradually and to demand from the athlete the efforts of will though to be surmountable (Williams et al. 2000; Ryska, 2004).

The article analyzes which traits of the will are the most characteristic of basketball players (cadets), and what the difference between the level of will traits among basketball-playing boys and girls is. When seeking the set goal, the following tasks have been solved: to reveal will traits of basketball players (boys and girls) by applying the method of self-evaluation; to investigate will traits of basketball players (boys and girls) by applying the method of expert evaluation.

It is presumed that the level of will traits in male basketball players (cadets) is higher than that of basketball-playing girls.

The research employed the following methods: a questionnaire-based survey (modified T. Dembo and S. Rubinstein methods (Елисеев, 1994)) to determine the level of expression of volitional features, the method of expert-evaluation to study determination and initiative (Palaima, 1984), and mathematical statistics $\left(\chi^{2}\right.$ test).

When applying a random selection procedure in basketball clubs for junior players of Kaunas district, the tested sample of 116 players included boys teams from Kaunas basketball club "Žvaigždžiu Tornadas" and basketball teams "Jotvingiai" and "Vidzgiris" (girls) from Alytus sport school. In total, 58 male basketball players aged 15 to 16 and 58 female basketball players aged 15 to 16 have been tested.

Having applied the method of questionnaire-based survey it was established that the distribution of male and female basketball players according to determination and courage differed statistically significantly: boys were more resolved $(\mathrm{p}<0.01)$ and more courageous $(\mathrm{p}<0.05)$ than girls. In addition, boys were more purposeful $(\mathrm{p}<0.05)$. When investigating will traits of basketball players (boys and girls) by applying the method of expert evaluation, it was proved that male basketball players were more characteristic of determination $(\mathrm{p}<0.01)$ than female basketball players. However, when applying the $\chi^{2}$ test it was established that young male and female players aged 15 to 16 did not statistically significantly differ in regard to initiative $\left(\chi^{2}(2)=0.34 ; p>0.05\right)$.
\end{abstract}

Keywords: will, will traits, basketball.

Gauta 2006 m. birželio 28 d.

Received on June 28, 2006

Priimta 2006 m. gruodžio $6 \mathrm{~d}$.

Accepted on December 6, 2006
Romualdas Malinauskas

Lietuvos kūno kultūros akademija

(Lithuanian Academy of Physical Education)

Sporto g. 6, LT-44221 Kaunas

Lietuva (Lithuania)

Tel +370 37231560

E-mail r.malinauskas@1kka.1t. 